\title{
Enzymatic Detachment of Therapeutic Mesenchymal Stromal Cells Grown on Glass Carriers in a Bioreactor
}

\author{
Denise Salzig $^{1, *}$, Alexandra Schmiermund ${ }^{1}$, Pablo P. Grace ${ }^{1}$, Christiane Elseberg $^{1}$, Christian Weber ${ }^{1}$ \\ and Peter Czermak ${ }^{1,2,3}$
}

${ }^{1}$ Institute of Bioprocess Engineering and Pharmaceutical Technology, University of Applied Sciences Mittelhessen, Wiesenstraße 14, 35390 Giessen, Germany

${ }^{2}$ Faculty of Biology and Chemistry, Justus-Liebig-University of Giessen, Germany

${ }^{3}$ Department of Chemical Engineering, Kansas State University, Manhattan, KS 66506, USA

\begin{abstract}
Cell therapies require the in vitro expansion of adherent cells such as mesenchymal stromal cells (hMSCs) in bioreactor systems or other culture environments, followed by cell harvest. As hMSCs are strictly adherent cells, cell harvest requires cell detachment. The use of hMSCs for cell therapy requires GMP production in accordance with the guidelines for advanced therapeutic medical products. Therefore, several GMP-conform available proteolytic enzymes were investigated for their ability to promote hMSC detachment. An allogeneic hMSC cell line (hMSC-TERT) that is used in clinical trials in the form of alginate cell capsules was chosen as a model. This study investigated the influence of several factors on the outcome of proteolytic hMSC-TERT detachment. Therefore, hMSC-TERT detachment was analyzed in different cultivation systems (static, dynamic) and in combination with further cell processing including encapsulation. Only two of the commercially available enzymes (Accutase ${ }^{\mathrm{TM}}$, TrypZean ${ }^{\mathrm{TM}}$ ) that fulfill all process requirements (commercial availability, cost, GMP conditions during manufacturing and non-animal origin) are found to be generally suitable for detaching hMSC-TERT. Combining cell detachment with encapsulation demonstrated a high impact of the experimental set up on cell damage. It was preferable to reduce the temperature during detachment and limit the detachment time to a maximum of 20 minutes. Cell detachment in static systems was not comparable with detachment in dynamic systems. Detachment yields in dynamic systems were lower and cell damage was higher for the same experimental conditions. Finally, only TrypZean ${ }^{\mathrm{TM}}$ seemed to be suitable for the detachment of hMSC-TERT from dynamic reactor systems.
\end{abstract}

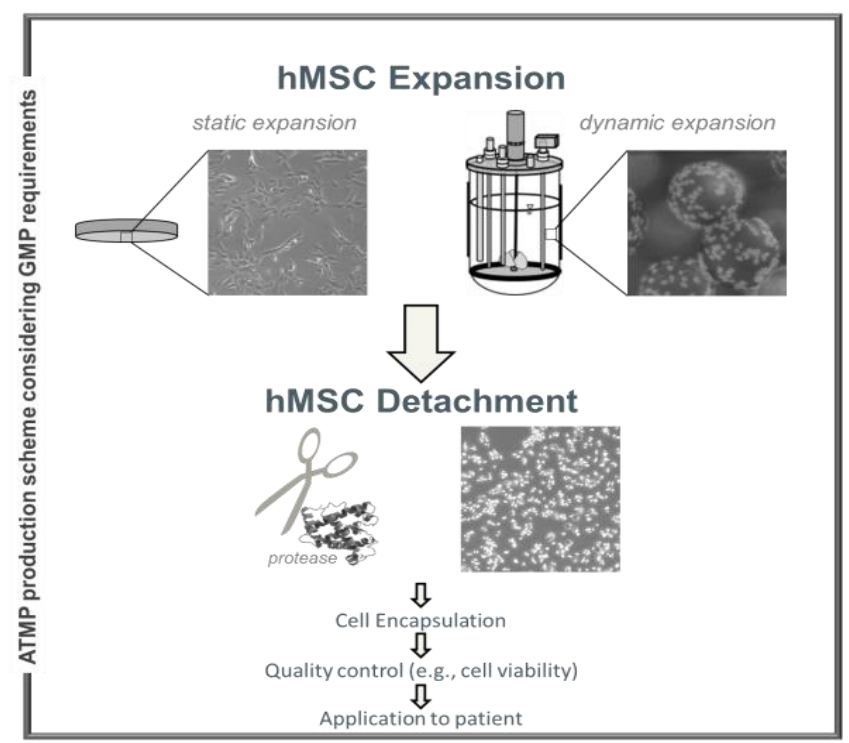

Keywords: ATMP, bioreactor, enzymatic detachment, glass carrier, hMSC.

\footnotetext{
*Address correspondence to this author at the Institute of Bioprocess Engineering and Pharmaceutical Technology, University of Applied Sciences Mittelhessen, Wiesenstraße 14, 35390 Giessen, Germany; Tel.: +49-641-309-2634; Fax: +49-641-309-2553;

E-mail: denise.salzig@kmub.thm.de
}

\section{INTRODUCTION}

Stem cells are one of the most important tools in cell therapy. They can be used to treat many diseases including diabetes mellitus and stroke [1]. In particular, human 
mesenchymal stromal cells (hMSC) are highly promising for further applications in cell therapy. One example of the use of hMSCs in cell therapy is the CellBead ${ }^{\circledR}$ technology (CellMed AG, a subsidiary of BTG plc.). CellBead ${ }^{\circledR}$ is an implantable cell therapeutic system based on a genetically modified hMSC cell line (hMSC-TERT) encapsulated in alginate, and is under a clinical trial for stroke treatment (clinical trial number: NCT01298830). The microcapsules enable the application of allogeneic stem cells without "graft-versus-host-disease" [2].

As stem cells become increasingly important for therapeutic treatments, enormous amounts of these cells will need to be produced. This is critical, because hMSCs only grow in adherent culture. Based on a therapeutic dose ranging from 1.5 to $120 \cdot 10^{6} \mathrm{hMSCs}$ [3] and a maximum expansion of 100,000 hMSCs per $\mathrm{cm}^{2}$, a growth surface of between 10 and $1,200 \mathrm{~cm}^{2}$ is required for a single dose. When using allogeneic hMSCs, the cell therapeutic can be produced as a stock. In this case, one production process should yield 100 doses. This means that a growth surface as large as $120,000 \mathrm{~cm}^{2}$ could be required, corresponding to 400 T-300 flasks to produce only 100 doses. Similar amounts of cells can be easily obtained using one $6.4 \mathrm{~L}$ fixed bed reactor or one $22 \mathrm{~L}$ stirred tank reactor. Bioreactors present advantages including low personnel demand, high space-time yield, a high level of automation of the cultivation, and a high level of control over the cell harvest and process control [4]. In conclusion, bioreactors should be the system of choice for hMSC expansion.

The hMSC production process is special in that the expanded cell is the product itself. In conventional processes such as antibody production, the production cells are discarded at the end of the process. In a stem cell expansion process, the production cell has to be harvested and removed from the reactor vessel in a high amount and at a high viability.

In this study, the hMSC-TERT cell line was used as a representative of therapeutically applied hMSCs. As hMSCTERT are adherently growing cells, carriers can be used to provide a suitable growth surface for a bioreactor expansion [5]. For the hMSC-TERT expansion processes in this work, non-porous and uncoated glass carriers were chosen. These carriers have been shown to be ideal as they on the one hand promote enough cell attachment and cell growth for an efficient expansion and on the other hand enable cell detachment [5]. This is not naturally given for all carriers as most of them are only optimized for strong cell adherence but not for cell detachment. With suitable carriers hMSC can be expanded in several cultivation systems. Many are known for their applicability to hMSC expansion, including fixed bed systems [4, 6, 7] and stirred tank reactors [3, 8]. The common characteristic of all hMSC expansion systems is that the adherent stem cells have to be detached from the growth surface at the end of the expansion process.

One standard method of hMSC detachment is proteolytic cleavage via proteases. The cell adherence in vitro is based on peptide bonds formed between medium proteins and extracellular cell surface proteins [9]. Positive charged medium proteins (mainly serum proteins as fibronectin ( $\mathrm{pI}$ 5.3)) adsorb to the negative charged plastic or glass surfaces.
Based on electrostatic interactions negative charged cells stick to the medium proteins. Finally covalent bonds were formed between the protein surface layer and integrins on the cell surface. As a consequence of this mode of attachment, adherent cells can be detached via proteolytic cleavage. The most commonly used protease for this purpose is bovine or porcine trypsin isolated from the pancreas. Despite its widespread use, trypsin presents several disadvantages for the detachment of cells that will be used therapeutically. First, trypsin is of animal origin. hMSCs used as advanced therapeutic medical products (ATMPs) fall under the guidance of the American Food and Drug Administration (FDA) and the European Medicines Agency (EMA). These guidelines hold that the amount of raw materials of animal origin used during the production of ATMPs should be minimized because of ethical and safety reasons [10]. Second, longer incubation times with trypsin can result in irreversible damage to the cell surface proteins [11], which would interfere with the aim of producing highly viable hMSCs for therapeutic application. For example, strong trypsinization of neural stem cells led to a reduction in cell viability and growth. This outcome was caused by the destruction of membrane receptors and cell adhesion molecules [12]. Third, trypsin should be used for hMSC expanded in a bioreactor system and for hMSCs which will be encapsulated after detachment. At first glance this has nothing to do with each other. On a closer look, however, it becomes apparent that the enzyme must fit to the cultivation system and to the further processing of the cells. In bioreactors dynamic cultivation is performed which causes higher cell stress during cell growth. Similar to that an encapsulation procedure applies shear stresses to the detached cells. Shear stress during cell growth and further cell processing means that the cells are handicapped and not as robust against potential damage from the detachment enzyme. Moreover, the forces responsible for cell detachment differ between dynamic (e.g., bioreactors) and static systems (e.g., T-flasks). In static systems, the enzymatic detachment is promoted by tapping. The tapping results in brief but strong shear forces that help to detach the cells. In contrast, tapping is not possible in dynamic systems. After enzymatic cleavage, detached cells are simply flushed out of the reactor. The resulting shear forces of the fluid flow are much weaker than those resulting from tapping. In consequence the detachment enzyme must be very efficient in dynamic systems as detachment is not supported by mechanical forces. Therefore, the enzymatic cleavage of hMSCs grown on carriers in dynamic systems must be as efficient but also as gentle as possible. Therefore, mammalian trypsin has certain disadvantages for the harvest of therapeutic stem cell products.

As summarized in Table 1, several other enzymes tend to be suitable for hMSC detachment in an ATMP production process. Out of this list four enzyme candidates (Accutase ${ }^{\mathrm{TM}}$, Alfazyme, Collagenase and TrypZean ${ }^{\mathrm{TM}}$ ) were favored considering additional characteristics including commercial availability, cost, GMP conditions during manufacturing and non-animal origin. These enzymes have already been used to remove various adherent cells from culture surfaces but never for the detachment of bioreactor-expanded hMSCs. Accutase $^{\text {TM }}$ (PAA) contains a mixture of proteases and 
Table 1. Enzymes for the Harvest or Subcultivation of Mammalian Adherent Cells

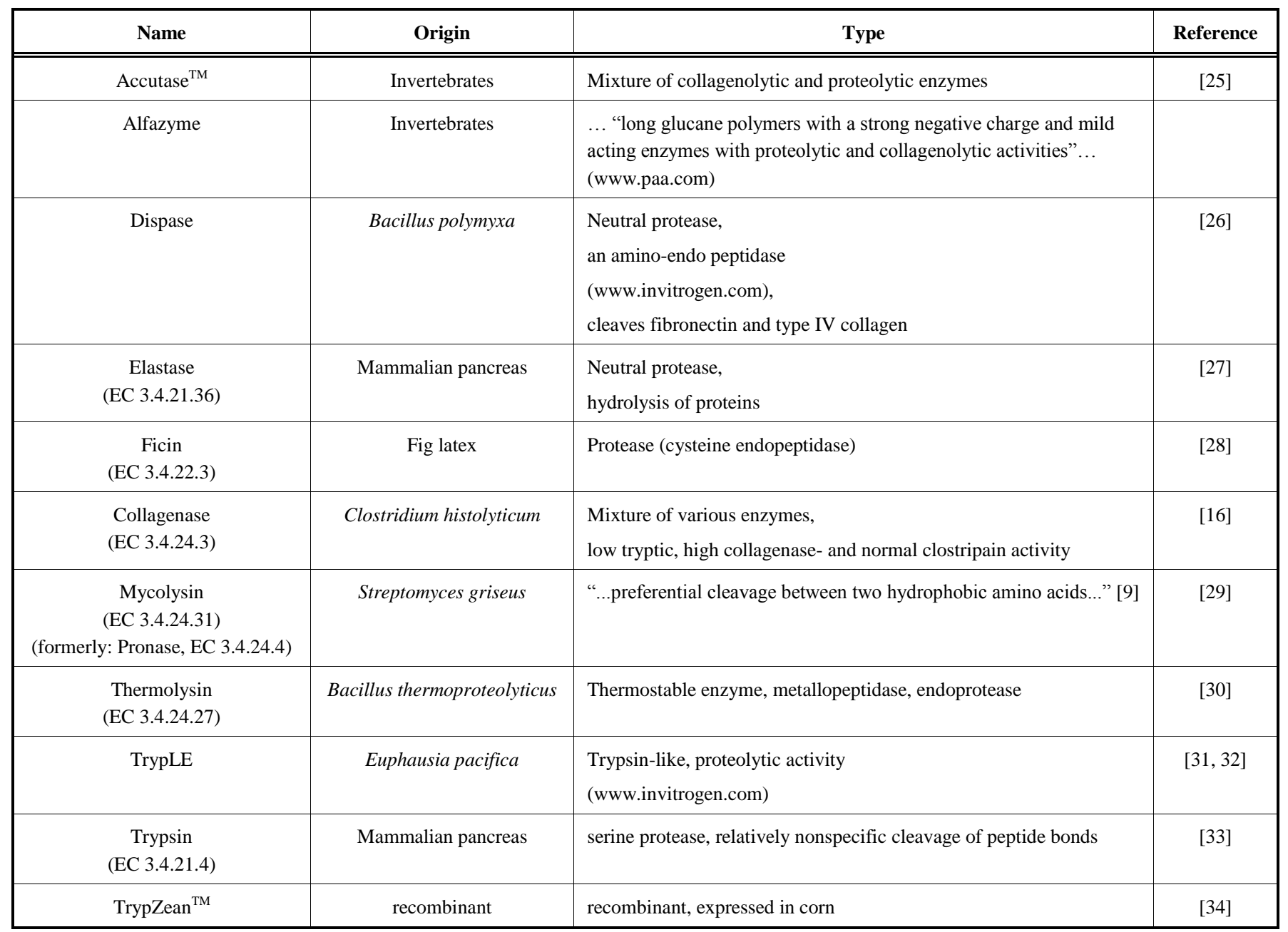

collagenases from invertebrate species, and has already been successfully used in stem cell detachment experiments. The viability, proliferation rate and pluripotency of human embryonic cells did not change after treatment with Accutase $^{\mathrm{TM}}$ [13]. In contrast to trypsin treatment, Accutase $\mathrm{T}^{\mathrm{TM}}$ does not affect the extracellular matrix (ECM) proteins [11]. Neural stem cells detached with Accutase ${ }^{\mathrm{TM}}$ had a viability of 90 to $95 \%$ compared with 70 to $80 \%$ after trypsin treatment [12]. Alfazyme (PAA) contains a mixture of proteolytic and collagenolytic enzymes as well as long glucane polymers with a strong negative charge. These glucane polymers are able to increase cell stability after detachment and thus to increase cell viability (www.paa.com). Vielreicher et al. demonstrated that the cell membranes of $\mathrm{CHO}$ cells (chinese hamster ovary) were not modified even after one hour treatment with Alfazyme at $37^{\circ} \mathrm{C}$ [14]. Related to stem cell detachment, Alfazyme has also been used to dissociate neural stem cell neurospheres [15]. Collagenase is a neutral protease without cytotoxic effects [16] and can also be used for cell detachment. Human embryonic stem cells have already been harvested from the cultivation surface using collagenase, with a viability of $88 \%$ after enzymatic treatment [17]. TrypZean ${ }^{\text {TM }}$ (SigmaAldrich) is a recombinant trypsin variant produced in corn. In contrast to animal-derived trypsin, TrypZean ${ }^{\mathrm{TM}}$ is naturally free of animal contaminants. Rourou et al. used TrypZean ${ }^{\mathrm{TM}}$ to detach Vero cells. In comparison with other enzymes, cells detached with TrypZean ${ }^{\mathrm{TM}}$ achieved the highest cell division number after enzymatic treatment [18]. TrypZean $^{\mathrm{TM}}$ has also been successfully used to harvest human MSCs for cardiac repair [19].

This study investigates the enzymatic detachment of therapeutic mesenchymal stromal cells grown on glass surfaces in static and dynamic cultivation systems. The ATMP model cell line hMSC-TERT was chosen for these experiments. As it is the aim to investigate alternatives to standard trypsin, four enzyme candidates (Accutase ${ }^{\mathrm{TM}}$, Alfazyme, Collagenase and TrypZean ${ }^{\mathrm{TM}}$ ) were selected. The first part of the study analyzes the detachment efficiency of the enzymes in static systems. Detachment time and temperature were varied to find the best enzyme candidate and the best parameters for further experiments. The experiments were evaluated in terms of detachment efficiency and the survival and viability of the cells directly after the harvest and after encapsulation in alginate. The second part of the study involved the investigation of cell detachment in dynamic systems. Therefore, hMSC-TERT cells expanded in different dynamic systems (fixed-bed reactor and stirred tank reactor) were harvested by the most 
promising enzyme candidates. The outcome of the cell detachment was analyzed as described above for the detachment efficiency and cell status.

\section{MATERIALS AND METHODS}

\subsection{Cultivation of hMSC-TERT in 6-well Plates}

This study used a hMSC cell line (hMSC-TERT) [20]. Cultivation and harvest of hMSC-TERT were performed according to standard procedures [5]. hMSC-TERT were cultured in 6-well plates (Techno Plastic Products AG, Trasadingen, Austria). To ensure comparability with the dynamic expansion process on borosilicate glass carriers in a fixed bed or stirred tank reactor, borosilicate glass plates (Thermo Scientific Mezel- Gläser, Braunschweig, Germany) with a diameter of $32 \mathrm{~mm}$ were placed in the wells. Wells were filled with $3 \mathrm{~mL}$ MEM cultivation media (PAA, Pasching, Austria), supplemented with $2 \mathrm{mM}$ L-Glutamine (PAA, Pasching, Austria) and $10 \%$ (v/v) FCS (Fetal Calf Serum) (PAA, Pasching, Austria), and maintained at $37^{\circ} \mathrm{C}$ and $5 \% \mathrm{CO}_{2}$ in an incubator (MMMgroup, Planegg, Germany). Cells were harvested at $80 \%$ confluence from a tissue culture flask (T-flask) (Sarstedt, Nümbrecht, Germany) following the standard procedure and seeded in the well plates at a density of 10,000 or 15,000 cells $/ \mathrm{cm}^{2}$, depending on the day of harvest. hMSC-TERT were grown to a cell density of 80,000 cells $/ \mathrm{cm}^{2}$.

\subsection{Cell harvest from Static Systems}

Four different enzyme solutions were tested. Accutase ${ }^{\mathrm{TM}}$ (400-600 U/mL, Sigma-Aldrich Chemie GmbH, Munich, Germany), Alfazyme (U/mL not specified, PAA, Pasching, Austria) and TrypZean ${ }^{\mathrm{TM}}$ (U/mL not specified, SigmaAldrich Chemie GmbH, Munich, Germany) are commercially available ready-to-use solutions. Collagenase $\mathrm{NB}$ 4G (from $\mathrm{Cl}$. Hyistolyticum, $0.27 \mathrm{PZU} / \mathrm{mg}$, SERVA Electrophoresis $\mathrm{GmbH}$, Heidelberg, Germany) was dissolved in phosphate buffered saline (PBS) without $\mathrm{Ca}^{2+} / \mathrm{Mg}^{2+}$ (PAA, Pasching, Austria) to a concentration of $0.18 \mathrm{U} / \mathrm{mL}$. Trypsin/EDTA (ready to use solution, PAA) was used as control.

The cell culture medium in the wells was removed and discarded. hMSC-TERT monolayers were rinsed twice with $1 \mathrm{~mL}$ PBS without $\mathrm{Ca}^{2+} / \mathrm{Mg}^{2+}$. Then, $1 \mathrm{~mL}$ of the corresponding enzyme solution was added. Incubation with the enzyme solution was done at $21^{\circ} \mathrm{C}$ or $37^{\circ} \mathrm{C}$ for at least 60 min. According to the manufacturers' recommendations, the enzymatic reactions of Accutas $^{\mathrm{TM}}$, Alfazyme and TrypZean $^{\text {TM }}$ were stopped using $1 \mathrm{~mL}$ sera-containing cultivation media. The reaction of the enzyme collagenase was stopped with bovine serum albumin $(5 \mathrm{mg} / \mathrm{mL})$ (Carl Roth GmbH, Karlsruhe, Germany). After gently pipetting of the stop solution on the cell layer, the layers were analyzed by microscopy (Leica Microsystems GmbH, Wetzlar, Germany) and the supernatant was removed. The cells in the supernatant were kept for encapsulation and further analysis.

\subsection{Cell Harvest from the Fixed-Bed Reactor}

hMSC-TERT were expanded on spherical borosilicate carriers (Worf, Mainz, Germany; $\varnothing 2 \mathrm{~mm}$ ) in a $100 \mathrm{~cm}^{3}$ fixed-bed system. Detailed information concerning the reactor set-up and the cultivation parameters were previously described [6]. To detach the cells, the medium was removed and the fixed-bed was washed with $200 \mathrm{~mL}$ PBS in perfusion mode $\left(v=1.8 \times 10^{-4} \mathrm{~m} \mathrm{~s}^{-1}\right)$. Thirty $\mathrm{mL}$ of the enzyme solution was pumped into the reactor $\left(v=1.8 \times 10^{-4} \mathrm{~m} \mathrm{~s}^{-1}\right)$ and the cells were incubated for 10 to $20 \mathrm{~min}$ at $21^{\circ} \mathrm{C}$. At the end of the incubation time, detached cells and enzyme solution were flushed out of the system with $200 \mathrm{~mL}$ cell culture medium $\left(v=3.2 \times 10^{-3} \mathrm{~m} \mathrm{~s}^{-1}\right)$. Cells were kept for encapsulation and further analysis.

\subsection{Cell harvest from the Stirred Tank Reactor}

hMSC-TERT were grown on polystyrene carriers coated with high silica glass (Solohill glass, Solohill Engineering, Ann Arbor, USA; $\varnothing 125-212 \mu \mathrm{m}$ ) in a $3 \mathrm{~L}$ stirred tank reactor. Reactor setting and cultivation parameters were previously described [8]. For cell harvest, $350 \mathrm{~mL}$ of the cell-carrier suspension was removed. Using a $100 \mu \mathrm{m}$ sieve, the medium was removed from the carriers with cells. The hMSC-TERT on the carrier were washed with $50 \mathrm{~mL}$ PBS$\mathrm{Ca}^{2+} / \mathrm{Mg}^{2+}$ and incubated with $16 \mathrm{~mL}$ enzyme solution for $15 \mathrm{~min}$ at $21^{\circ} \mathrm{C}$. To stop the detachment, $50 \mathrm{~mL}$ of cell culture medium were added. Detached cells were rinsed through the sieve with the medium. The harvested cells were kept for encapsulation and further analysis.

\subsection{Quantification of Detachment}

In static systems the detachment efficiency was determined as followed. Cells were grown to a final density of 80,000 cells $\mathrm{cm}^{-2}$ and detached as described above. During the detachment period, detached cells were quantified in 3 wells of a 6-well plate. Detachment reaction was stopped and the supernatant of these wells was removed. The cells in the supernatant (=detached cells) were counted by the Trypan blue method (Biowest, Neuville, France) following a standard procedure [21]. The detachment efficiency was calculated using equation 1 :

$$
\text { detached cells [\%] } 100 \frac{\text { cells counted in the supernatant }}{80,000 \text { cells } \mathrm{cm}^{-2}}
$$

In dynamic systems the detachment was quantified very similar. At the end of the detachment period the cells in the supernatant were counted by the Trypan blue method. Cells remaining on the carriers after detachment were determined by a SybrGreen assay [22]. The detachment efficiency in dynamic systems was calculated using equation 2 .

$$
* \frac{\text { detached cells }[\%] 100}{\text { cells counted in the supernatant }}
$$

\subsection{Encapsulation of hMSC-TERT}

After harvest, the cells were encapsulated in alginate. hMSC-TERT cells were resuspended at a concentration of $5 \times 10^{6}$ cells in $5 \mathrm{~mL}$ of $5 \mathrm{mM} \mathrm{NaCl}$-His and gently mixed with $1.5 \%$ (w/v) alginate (Carl Roth GmbH, Karlsruhe, Germany) using a $1 \mathrm{~mL}$ syringe (B. Braun, Melsungen, 
Germany) and a G21 cannula. Droplets were formed by pipetting the mixture in a $20 \mathrm{mM} \mathrm{BaCl}_{2}$ bath. After incubation in $20 \mathrm{mM} \mathrm{BaCl}$ for $60 \mathrm{~min}$, the spherical beads $(\varnothing 500 \mu \mathrm{m})$ were washed $3 \mathrm{x}$ with PBS with $\mathrm{Ca}^{2+} / \mathrm{Mg}^{2+}$ (PAA, Pasching, Austria). Afterwards, the cell capsules were recultivated for $48 \mathrm{~h}$ in $1 \mathrm{~mL}$ MEM medium in a 6-well-plate in an incubator at $5 \% \mathrm{CO}_{2}$ and $37^{\circ} \mathrm{C}$.

\subsection{Live-dead-Staining of Alginate Encapsulated Cells}

To prepare the staining solution, a SybrGreen (SigmaAldrich Chemie GmbH, Munich, Germany) working solution was prepared containing $20 \%$ SybrGreen $(1: 500$ in DMSO, Dimethylsulfoxide), $60 \%$ Tris-HCl- buffer $(20 \mathrm{mM}$, $\mathrm{pH} 8)$ and $20 \%$ EDTA (100 mM, pH 8). The staining solution was prepared by mixing $87 \% \mathrm{PBS}$ with $\mathrm{Ca}^{2+} / \mathrm{Mg}^{2+}$, $4.4 \%$ propidium iodide $(5 \mathrm{~g} / \mathrm{L})$ and $8.6 \%$ SybrGreen (working solution). Staining was performed direct after encapsulation, after $24 \mathrm{~h}$ and $48 \mathrm{~h}$ recultivation. The capsules were washed $3 \mathrm{x}$ with $1 \mathrm{~mL}$ PBS- $-\mathrm{Ca}^{2+} / \mathrm{Mg}^{2+}$ per $1 \mathrm{~mL}$ capsules to remove the remaining serum containing media. Then, $200 \mu \mathrm{L}$ of staining solution was added and incubated for $5 \mathrm{~min}$ at room temperature in the dark. After incubation, the capsules were washed again with $1 \mathrm{~mL}$ PBS-Ca ${ }^{2+} / \mathrm{Mg}^{2+}$ $(5 \mathrm{x})$. The live-dead analysis was performed microscopically.

\subsection{Quantitative Analysis of the Live-Dead-Staining of Alginate Encapsulated Cells}

Using a fluorescence microscope (DMI6000; Leica Microsystems GmbH, Wetzlar, Germany) and a HCX PL FLUOTAR 10.0x0.30 DRY objective, pictures of the stained capsules were taken. Using a constant setting each fluorescence canal was saved separately. The green fluorescence was detected with a L5 filter cube (ex. 480/40, em. 527/30) using an exposure time of $60 \mathrm{~ms}$ and a gain of 2 . The red fluorescence was detected with a N3 cube (ex. 546/12, em. 600/40) with similar exposure time and gain. This resulted in two fluorescence images, one for the green and one for the red fluorescence. The quantitative analysis of the images was done with the free ware program ImageJ. Therefore each image was transformed into a 8-bit picture. After that a macro (the code of the macro is shown below) counted the fluorescent cells within the picture.

$$
\begin{aligned}
& >\text { macro QuantSlide }\{ \\
& >\mathrm{w}=\operatorname{getWidth}() ; \\
& >\mathrm{h}=\operatorname{getHeight}() ; \\
& >\text { treshold }=30 ; \\
& >\text { counter }=0 ; \\
& >\text { for }(\mathrm{i}=0 ; \mathrm{i}<\mathrm{w} ; \mathrm{i}++)\{ \\
& >\quad \text { for }(\mathrm{j}=0 ; \mathrm{j}<\mathrm{h} ; \mathrm{j}++)\{ \\
& >\quad \mathrm{a}=\text { getPixel }(\mathrm{i}, \mathrm{j}) ; \\
& >\quad \text { if }(\mathrm{a}>=\operatorname{treshold})\{ \\
& >\quad \quad \quad \text { counter }=\text { counter }+1 ; \\
& >\quad\} \quad \\
& >\} \quad\}
\end{aligned}
$$

The viability was determined as followed:

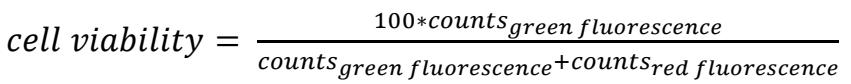

\subsection{Statistical Analysis}

For all quantitative data mean and standard deviation were calculated. To compare the mean values a t-test (two sample test with known variances) was performed. A p-value under 0.05 was deemed to indicate a statistically significant difference.

\section{RESULTS AND DISCUSSION}

The main objective of this work was to investigate different detachment enzymes for the harvest of therapeutic hMSCs grown in dynamic systems. hMSC-TERT was chosen as a model cell line as these cells are already used in cell therapy approaches. hMSCs in general are strictly adherent cells, so that the expansion has to be performed on growth surfaces such as flasks or carriers. The unique factor in the production process of these cells is that after expansion, the cells have to be detached. As the cells are products of the expansion process, the harvest should be gentle but effective to yield large amounts of viable cells. This study examines which commercial available enzymes of non-mammalian origin are suitable for the detachment of hMSC-TERT cells. To improve the comparability of the results, the same enzyme concentration per $\mathrm{cm}^{2}$ was used in static and dynamic systems. The first experiments were performed in static systems (well plates) to select one or two candidate enzymes for further experiments. Then, hMSCTERT cells were expanded in different dynamic systems (fixed-bed reactor, STR) and harvested. The outcome of the harvest was analyzed in terms of the yield and viability of the detached cells. As these cells are further processed after the harvest, the cells were encapsulated in alginate. These cell capsules are the final cell therapy product that should be implanted into the patient. Viability staining was performed to analyze the cell quality in the capsule.

\subsection{Suitability of the Chosen Enzymes for hMSC-TERT Detachment from Static Systems}

Considering various criteria for the production of stem cell-based ATMPs, four different enzymes have been chosen for investigations of the enzymatic harvest of adherent hMSC-TERT: Accutase ${ }^{\mathrm{TM}}$, Alfazyme, Collagenase and TrypZean $^{\mathrm{TM}}$. In the initial experiments, hMSC-TERT grown as a monolayer in static well plates were detached. The cells were detached from a borosilicate glass surface to mimic the surface conditions of the dynamic systems where the cells grow on glass carriers. The cells were detached at room temperature $\left(21^{\circ} \mathrm{C}\right)$ for $60 \mathrm{~min}$ and the detachment was monitored by microscopy and quantified by counting the harvested cells. As shown in Fig. (1), only Accutase ${ }^{\mathrm{TM}}$ and TrypZean $^{\mathrm{TM}}$ were able to completely detach the hMSCTERT cells. In comparison, TrypZean ${ }^{\mathrm{TM}}$ was slightly more efficient, requiring only $8 \mathrm{~min}$ instead of $11 \mathrm{~min}$ for $100 \%$ detachment. The other two proteolytic enzymes Alfazyme and Collagenase seemed not to be suitable for hMSC-TERT 
detachment from glass surfaces. Even after $60 \mathrm{~min}$ incubation, these enzymes were only able to detach $30 \%$ of the cells at best.

Microscopic observation of the detachment reaction with Alfazyme and Collagenase (Fig. 1) showed that Alfazyme was not able to disrupt the cell-cell contacts, with cells detaching from the surface as cell sheets. This implied that Alfazyme was not able to split hMSC-TERT cadherins which are mainly involved in cell-cell-adhesion. Collagenase was able to separate cells but not to detach them from the surface. In consequence collagen was not involved in hMSCTERT-substrate-adhesion. Following out of the four enzyme candidates only Accutase $^{\mathrm{TM}}$ and TrypZean ${ }^{\mathrm{TM}}$ were used for further investigations.

\subsection{Influence of Enzyme Incubation Time on hMSC- TERT Detachment from Static Systems}

The initial results showed that Accutase $^{\mathrm{TM}}$ and TrypZean $^{\mathrm{TM}}$ are the most promising candidates for further investigation. As high amounts of hMSC-TERT are required for therapeutic use, the cells were exposed to each enzyme for 20 or $45 \mathrm{~min}$. This long incubation time might be necessary for an efficient hMSC-TERT detachment in the dynamic FBR and STR systems, because in general cells grown on carriers require longer incubation times to be
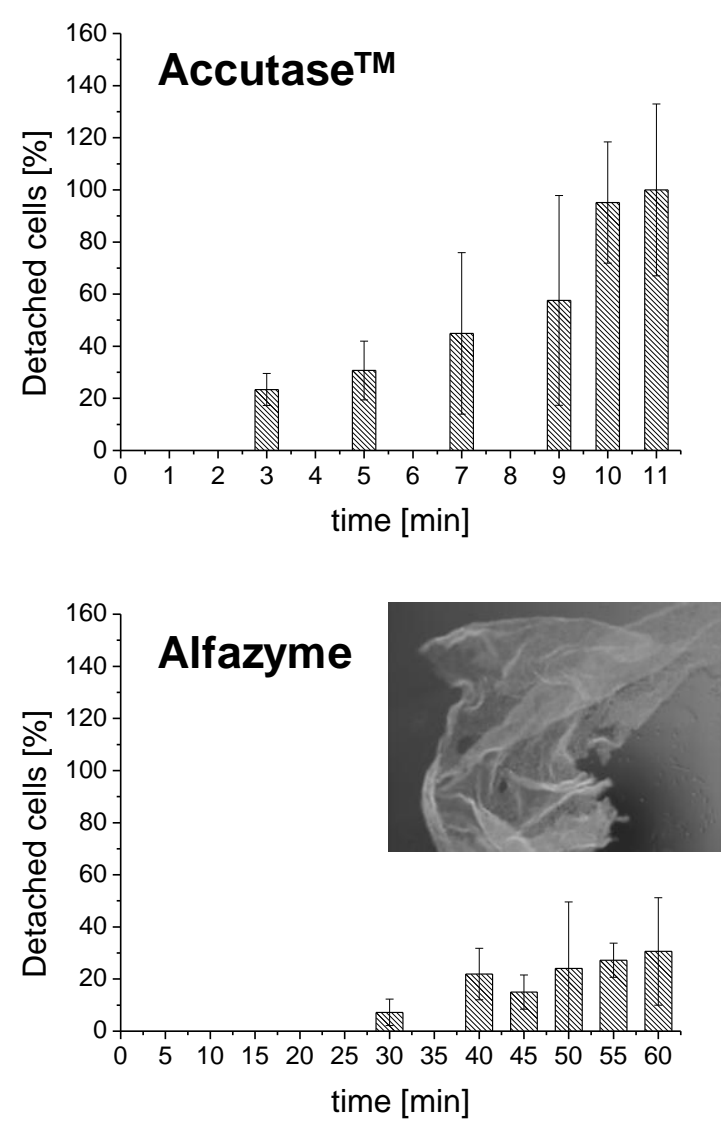

detached than cells grown in static monolayers [5]. With this experiment it should be investigated if these long enzyme incubation times might damage the hMSC-TERT. As control porcine trypsin under standard condition $\left(21^{\circ} \mathrm{C}, 10 \mathrm{~min}\right.$ incubation) was used. As shown before, cells were completely detached after $\sim 11$ minutes. Interestingly, even after $45 \mathrm{~min}$ incubation with these proteolytic enzymes, no decrease in cell viability occurred. This means that direct after the detachment no cell damage could be detached with Trypan blue staining. The decisive experiment is to evaluate the detachment quality by measuring cell viability after cell encapsulation. Because of their potential use in cell therapeutic approaches, the cells have to have a viability of at least $90 \%$ after encapsulation. This is challenging as the encapsulation procedure subjects the cells to further stress because cells are sheared through drain tubes and are influenced by changes in the osmotic environment and other stresses. Thus, hMSC-TERT were encapsulated in alginate after 20 or 45 minutes of enzyme treatment. The capsules were analyzed by live-dead staining directly after encapsulation and after $24 \mathrm{~h}$ and $48 \mathrm{~h}$ of static recultivation in cell culture medium.

As seen in Fig. (2), the detachment in combination with the encapsulation procedure exerted a strong influence on cell viability. Directly after encapsulation, many cells were damaged and cell membranes were disrupted, visible as red
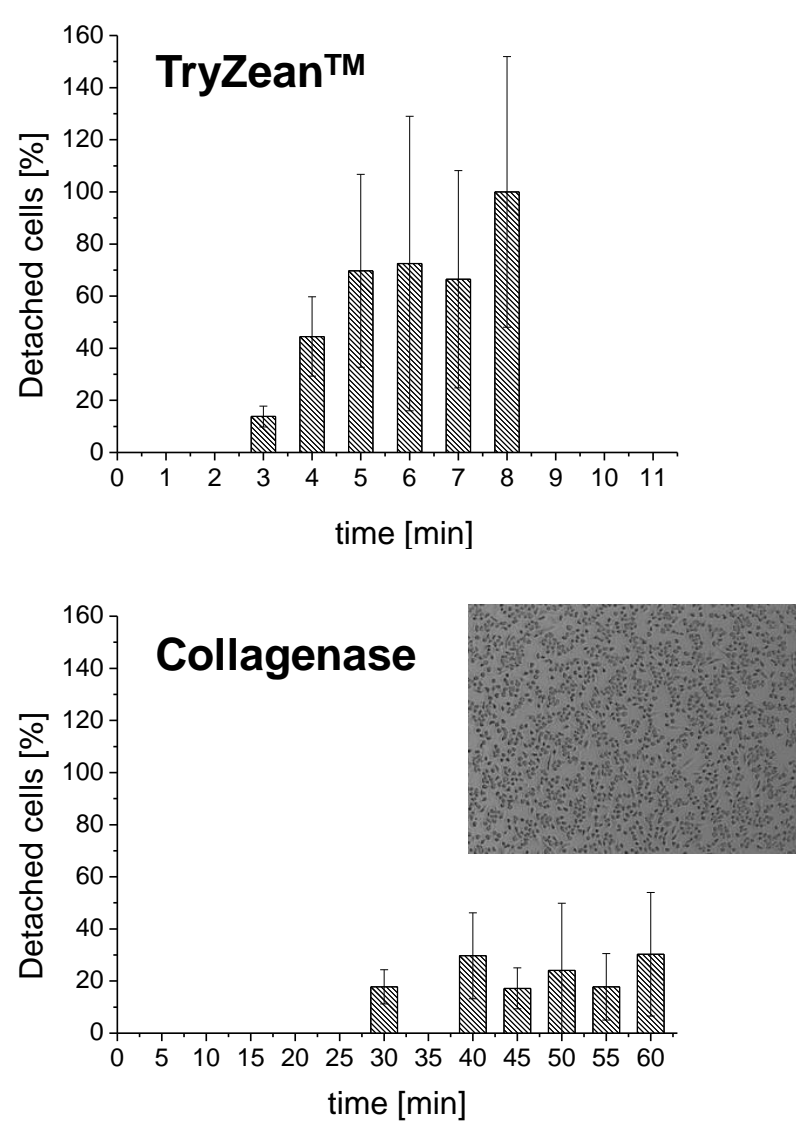

Fig. (1). Proteolytic detachment of hMSC-TERT grown statically as a monolayer on a borosilicate surface. hMSC-TERT were grown to $80 \%$ confluence in 6-well-plates on a borosilicate surface and washed twice with PBS without $\mathrm{Ca}^{2+} / \mathrm{Mg}^{2+}$. One $\mathrm{mL}$ of the enzyme solution (Accutase $^{\mathrm{TM}} \sim 100 \mathrm{U} / \mathrm{mL}$, Alfazyme (1:6), Collagenase $0.18 \mathrm{U} / \mathrm{mL}$, TrypZean ${ }^{\mathrm{TM}}(1: 6)$ ) was added and the plates were incubated at room temperature $\left(21^{\circ} \mathrm{C}\right)$ for at least $60 \mathrm{~min}$. Detachment was documented microscopically and the detached cells were counted; $\mathrm{n}=3$. Microscopic pictures showed the detachment result for Alfazyme (left) and Collagenase (right) after 60 min enzyme incubation. 
colored (= damaged) cells. During the recultivation period, cell membranes were able to regenerate, as the number of green colored $(=$ live) cells increased with recultivation time. The degree of cell damage increased with incubation time for detachment with TrypZean ${ }^{\mathrm{TM}}$ (20 min detachment: $91.2 \pm 1.6 \%$ viability; 45 min detachment: $69.4 \pm 2.8 \%$ viability, $\mathrm{p}<0.01)$. This was also the case for detachment with Accutase ${ }^{\mathrm{TM}}$ but less pronounced $(20 \mathrm{~min}$ detachment: $99.5 \pm 1.8 \%$ viability; $45 \mathrm{~min}$ detachment: $95.1 \pm 1.3 \%$ viability, $\mathrm{p}<0.05)$ ), supporting the argument that Accutase $^{\mathrm{TM}}$ seems to be gentler to the cells and less destructive to the cell surface and membrane proteins [11]. The standard cell culture detachment procedure (trypsin, 10 min incubation, $21^{\circ} \mathrm{C}$ ) led to a slight decrease in the cell viability $(95.8 \pm 1.4 \%)$ of the encapsulated cells. During recultivation the viability of the encapsulated cells could recover to $99.2 \pm 0.8 \%(\mathrm{p}<0.05)$. Note that the detachment enzyme and the length of the incubation only affect cell viability after harvest if the cells are processed further. Directly after the detachment, the cell viability remained high in all cases. An influence of the detachment procedure on cell viability could only be observed if the cells were encapsulated.

\subsection{Influence of Enzyme Incubation Temperature on hMSC-TERT Detachment from Static Systems}

In general, detachment enzymes are optimally active at $37^{\circ} \mathrm{C}$. This could be superior for cell detachment yield in dynamic systems as enzymes work more efficient. In contrast increasing the reaction temperature is likely to increase the potential proteolytic damage of the cells. To evaluate that influence, hMSC-TERT detachment was analyzed at $37^{\circ} \mathrm{C}$. The same experimental setup and conditions were used as in the previous experiment. The results are presented in Fig. (3).

hMSC-TERT harvested at $37^{\circ} \mathrm{C}$ and then encapsulated mostly exhibited viabilities below $50 \%$ after 48 hours of cultivation in alginate capsules, whereas at room temperature the cells in the capsules had viabilities > $95 \%$. After $20 \mathrm{~min}$ detachment with Accutase $\mathrm{T}^{\mathrm{TM}}$ at $37^{\circ} \mathrm{C}$ and subsequent encapsulation, first the amount of viable cells was $97.0 \pm 1.2 \%$. During recultivation of the cell capsules the viability dropped down to $43.3 \pm 5.2 \%$ ( $\mathrm{p}<0.01)$. Better results were observed for TrypZean ${ }^{\mathrm{TM}}$. Although after 20 min TrypZean ${ }^{\mathrm{TM}}$ treatment cell viability of the capsules was lower (direct after encapsulation: $84.5 \pm 2.6 \%$ ), the cells were able to regenerate during the recultivation period, yielding to a cell viability of $95.7 \pm 1.2 \% \quad(\mathrm{p}<0.01)$.

\begin{tabular}{|c|c|c|c|c|c|c|c|}
\hline & & & \multicolumn{2}{|c|}{ Accutase $^{\mathrm{TM}} 21^{\circ} \mathrm{C}$} & \multicolumn{2}{|c|}{ TrypZean $^{\mathrm{TM}} 21^{\circ} \mathrm{C}$} & Trypsin $21^{\circ} \mathrm{C}$ \\
\hline \multicolumn{3}{|c|}{$\mathbf{t}_{\text {detachment }}$} & $20 \min$ & $45 \min$ & $20 \mathrm{~min}$ & $45 \min$ & $10 \mathrm{~min}$ \\
\hline \multirow{6}{*}{ 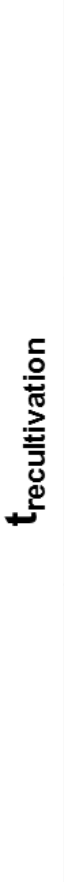 } & \multirow[t]{2}{*}{$\mathrm{Oh}$} & 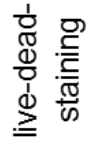 & & & & & \\
\hline & & 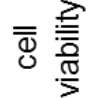 & $99.5 \pm 1.8 \%$ & $95.1 \pm 1.3 \%$ & $91.2 \pm 1.6 \%$ & $69.4 \pm 2.8 \%$ & $99.6 \pm 2.1 \%$ \\
\hline & \multirow[t]{2}{*}{$24 \mathrm{~h}$} & 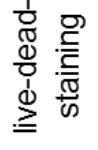 & & & & & \\
\hline & & $\overline{\overline{\mathcal{D}}} \frac{\mathrm{z}}{\overline{\mathrm{J}}}$ & $98.8 \pm 0.9 \%$ & $99.8 \pm 1.8 \%$ & $95.0 \pm 0.4 \%$ & $99.3 \pm 1.0 \%$ & $95.8 \pm 1.4 \%$ \\
\hline & \multirow[t]{2}{*}{$48 \mathrm{~h}$} & 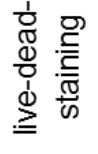 & 4 & & & & 88 \\
\hline & & 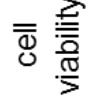 & $99.7 \pm 2.1 \%$ & $93.0 \pm 2.5 \%$ & $99.7 \pm 0.7 \%$ & $99.2 \pm 1.3 \%$ & $99.2 \pm 0.8 \%$ \\
\hline
\end{tabular}

Fig. (2). hMSC-TERT encapsulated in alginate after enzymatic detachment from borosilicate surfaces in 6 -well plates (21 $\left.{ }^{\circ} \mathrm{C}\right)$. hMSC-TERT cells were grown to $80 \%$ confluence in 6-well-plates on a borosilicate surface and washed twice with $\mathrm{PBS}$ without $\mathrm{Ca}^{2+} / \mathrm{Mg}^{2+}$. The enzyme solution $\left(0.13 \mathrm{~mL} / \mathrm{cm}^{2}\right.$; Accutase $\mathrm{e}^{\mathrm{TM}} \sim 100 \mathrm{U} / \mathrm{mL}$, TrypZean ${ }^{\mathrm{TM}}(1: 6)$ orTrypsin) was added and the plates were incubated at room temperature $\left(21^{\circ} \mathrm{C}\right)$ for 20 or $45 \mathrm{~min}$. Detached cells were encapsulated in alginate. The capsules were recultivated in hMSC-TERT culture medium in 6 well-plates for $48 \mathrm{~h}$ at $37^{\circ} \mathrm{C}$. The cell viability was analyzed by performing live-dead staining. Viable/intact cells were stained green whereas damaged/dead cells were stained red. 
However, after $45 \mathrm{~min}$ incubation, the cell viability continuously decreased during the recultivation period for both enzymes (Accutase ${ }^{\mathrm{TM}}$ : $92.6 \pm 3.4 \%$ (Oh) $-77.5 \pm 4.8 \%$ (24h) $-35.1 \pm 2.5 \%$ (48h), p < 0.01; TrypZean ${ }^{\mathrm{TM}}: 97.5 \pm 1.0$ $\%$ (0h)-88.7 $\pm 1.5 \%$ (24h)-47.3 $\pm 4.9 \%$ (48h), p < 0.01$)$, a good indication that cell damage was already present at the beginning of this period. Poor results were observed for the standard detachment enzyme trypsin. After 10 min trypsin detachment followed by encapsulation, cell membranes were disrupted as seen by the majority of red colored cells in Fig. (3) (cell viability direct after encapsulation $8.3 \pm 1.4 \%$ ). Some of these cells could be recovered, but the cell viability was still low after recultivation (cell viability during recultivation $73.8 \pm 2.1 \%(24 \mathrm{~h}), 64.8 \pm 3.6 \%$ (48h)). This investigation leads to the conclusion that the temperature during enzymatic harvest and the duration of enzyme exposure had significant impacts on the cell viability after detachment followed by encapsulation. For this type of production process and both investigated enzymes, detachment at room temperature $\left(21^{\circ} \mathrm{C}\right)$ with a maximum incubation time of 20 minutes was superior for the survival of the encapsulated hMSC-TERT. This led to cell capsules with viabilities of $99 \%$. This gave a good basis for the experiments in the dynamic systems.

\subsection{Harvest of hMSC-TERT Expanded in a Fixed-Bed Reactor}

The problem of balancing the detachment yield, which should be $100 \%$, and the applied cell stress induced by the detachment procedure, which should be minimal, is more complex in dynamic systems. To expand larger amounts of stem cells for therapeutic approaches, controlled bioreactor systems will need to be used such as fixed-bed or stirred tank reactors. Harvesting cells from these reactor systems has received relatively little study because in most biotechnological processes, cell detachment is not required. Therefore, most carriers for these systems, which are obligatory for stem cell expansion, are designed to promote strong adherence but not detachment. In previous studies, our workgroup identified carriers combining both characteristics: good attachment and growth of the hMSCTERT and enabling hMSC-TERT detachment [5]. With these glass carriers, a fixed-bed based expansion system for hMSC-TERT was set up [6,7]. Detailed studies of the detachment of the hMSC-TERT from this FBR were conducted using similar conditions to the static experiments described above. Based on the previous results, only Accutase $^{\mathrm{TM}}$ and TrypZean ${ }^{\mathrm{TM}}$ at $21^{\circ} \mathrm{C}$ with incubation times from 10 to 20 minutes were analyzed. Harvested cells were

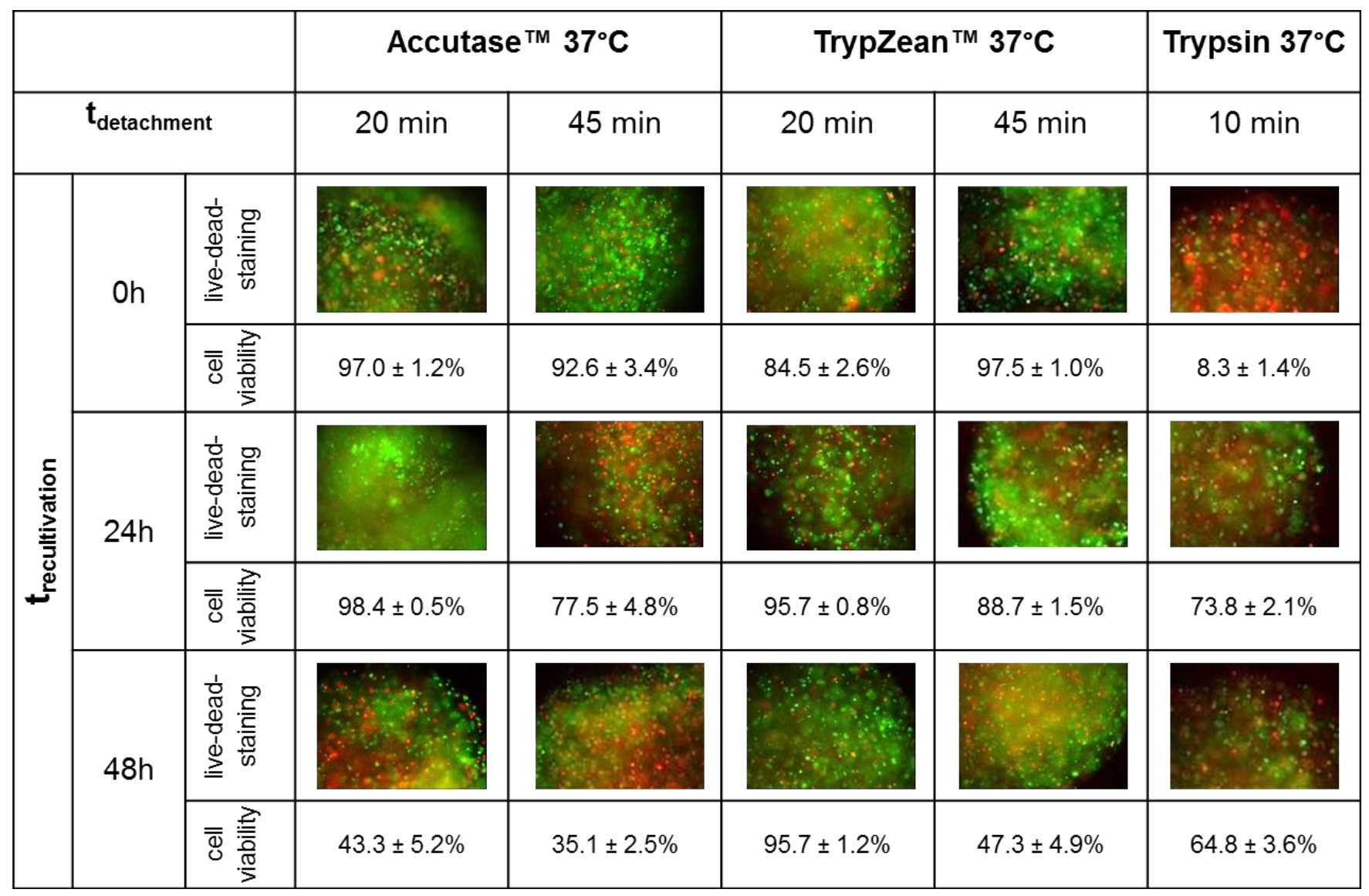

Fig. (3). hMSC-TERT encapsulated in alginate after enzymatic detachment from borosilicate surfaces in 6 -well plates (37 $\left.{ }^{\circ} \mathrm{C}\right)$. hMSC-TERT were grown to $80 \%$ confluence in 6-well-plates on a borosilicate surface and washed twice with $\mathrm{PBS}$ without $\mathrm{Ca}^{2+} / \mathrm{Mg}^{2+}$. The enzyme solution $\left(0.13 \mathrm{~mL} / \mathrm{cm}^{2}\right.$; Accutase $\mathrm{TM}^{\mathrm{TM}} \sim 100 \mathrm{U} / \mathrm{mL}$, TrypZean ${ }^{\mathrm{TM}}(1: 6)$ or Trypsin) was added and the plates were incubated at $37^{\circ} \mathrm{C}$ for 20 or $45 \mathrm{~min}$. Detached cells were encapsulated in alginate. The capsules were recultivated in hMSC-TERT culture medium in 6-well-plates for $48 \mathrm{~h}$ at $37^{\circ} \mathrm{C}$. The cell viability was analyzed using live-dead staining. Viable/intact cells were stained green whereas damaged/dead cells were stained red. 
further processed to alginate capsules and analyzed as described previously.

The first basic difference from the detachment experiments with the hMSC-TERT cells grown as monolayers in static systems (well plates) is that the harvest from the FBR was not that efficient (Table 2). A maximum of $\sim 70 \%$ of the hMSC-TERT grown in the FBR could be detached within the selected experimental conditions. Note that $100 \%$ detachment was reachable, but only with a dramatic loss in cell viability.

That cell viability is influenced more by hMSC-TERT detachment from FBR than by static cultivation systems as shown in Fig. (4). In dynamic systems, the detachment procedure results in other shear forces because the cells are flushed out of the system. Although a superficial velocity that should not affect cell viability was used [6], the duration of shear is longer compared to static systems. hMSC-TERT detached after 10 min Accutase ${ }^{\mathrm{TM}}$ treatment in the FBR exhibited very low viabilities after encapsulation with high standard deviations $(7.0 \pm 6.8 \%$ (0h) $-9.4 \pm 8.6 \%$ (24h)$21.21 \pm 20.7 \%(48 \mathrm{~h}), \mathrm{p}<0.01)$. When the detachment yield was relatively low (24\%), $13.9 \%$ of the hMSC-TERT in the alginate capsules stayed viable. Cell viability did only partly recover during recultivation, indicating that $60 \%$ of the red colored cells were dead right after detachment and encapsulation (Fig. (4), left hand). In one case, the harvest yield was over $80 \%$, but these cells were completely dead (Fig. (4), right hand). The cell viability of the encapsulated cells was max. $0.4 \%$ and could not recover during recultivation. Microscopic observation of the detachment showed that in this case, cells were not detached as single cells but rather torn off as cell sheets. The resulting shear forces were too high for cell survival. After $20 \mathrm{~min}$ of Accutase $^{\mathrm{TM}}$ treatment in the FBR the results were more homogenous, but both the detachment yield $(59 \pm 5 \%)$ and cell viability of hMSC-TERT after encapsulation were unsatisfactory $(52.6 \pm 4.7 \%$ after encapsulation and $48 \mathrm{~h}$ recultivation). hMSC-TERT grown in the FBR, detached with TrypZean ${ }^{\mathrm{TM}}$ and encapsulated exhibited a high viability right after the encapsulation for all investigated incubation times (10 min: $97.8 \pm 1.5 \%, 15 \mathrm{~min} 89.3 \pm 3.1 \%$ and $20 \mathrm{~min} \quad 92.4 \pm 2.1 \%$ ). Unfortunately, after $10 \mathrm{~min}$ detachment, the cell viability decreased during recultivation down to $63.0 \pm 2.1 \%$, indicating the presence of cell damage. This could result from the incomplete detachment of the cells. Cells were not gently flushed out of the FBR but were rather partially torn off. After 20 min detachment the similar decrease of cell viability during recultivation was observed but the reason for that might be different. In this

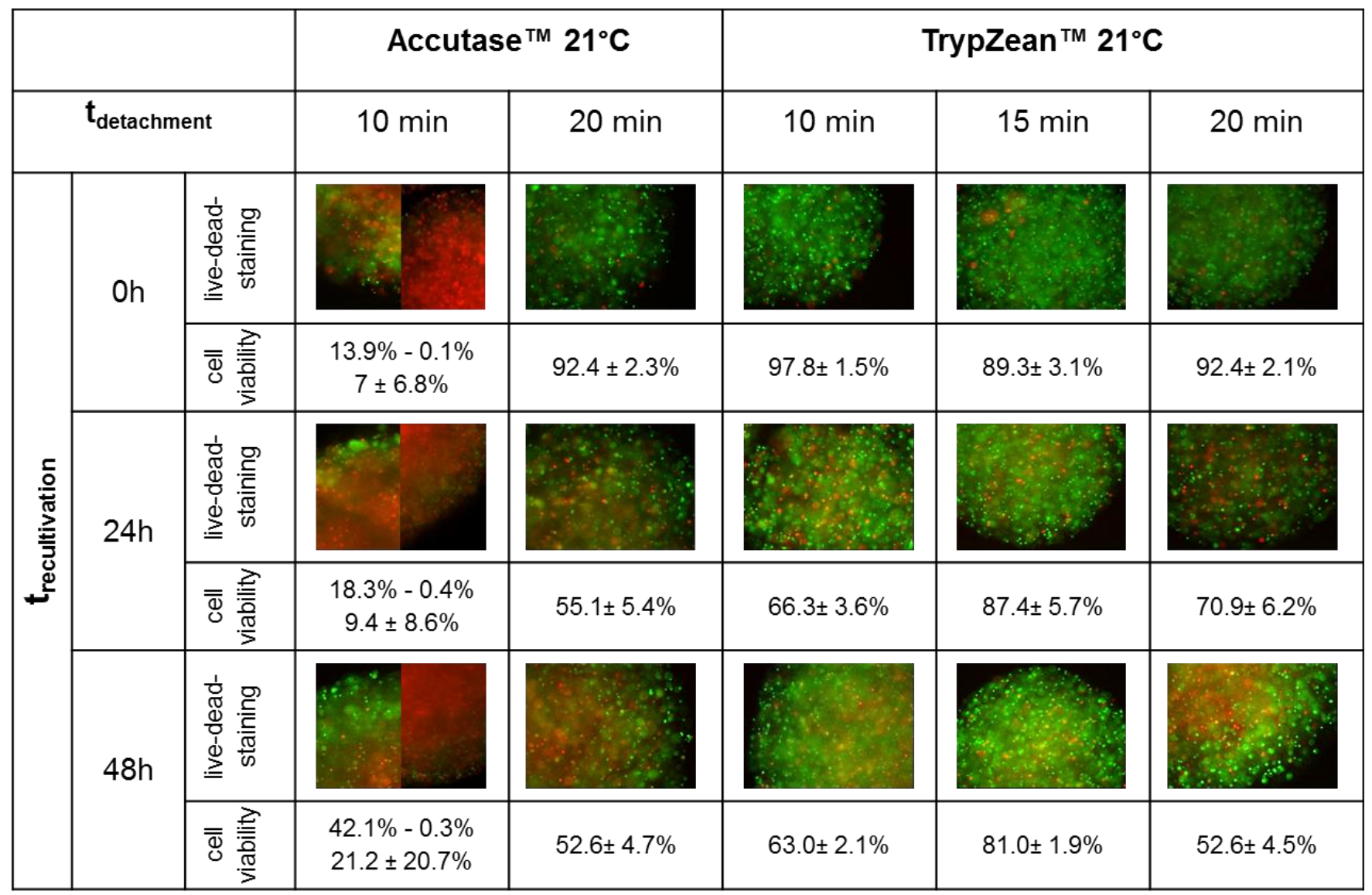

Fig. (4). hMSC-TERT encapsulated in alginate after enzymatic detachment from borosilicate carriers in a fixed-bed reactor $\left(21^{\circ} \mathrm{C}\right)$. hMSCTERT were grown in an $100 \mathrm{~cm}^{3}$ FBR and washed twice with PBS without $\mathrm{Ca}^{2+} / \mathrm{Mg}^{2+}$. The enzyme solution $\left(0.13 \mathrm{~mL} / \mathrm{cm}^{2}\right.$, Accutase ${ }^{\mathrm{TM}}$ $\sim 600 \mathrm{U} / \mathrm{mL}$ or TrypZean ${ }^{\mathrm{TM}}$ ) was added and the carriers were incubated at room temperature $\left(21^{\circ} \mathrm{C}\right)$ for 10,15 or 20 min. Detached cells were encapsulated in alginate. The capsules were recultivated in hMSC-TERT culture medium in 6-well-plates for $48 \mathrm{~h}$ at $37^{\circ} \mathrm{C}$. The cell viability was assessed using live-dead staining. Viable/intact cells were stained green whereas damaged/dead cells were stained red. 
Table 2. Detachment/Harvest yield from a Fixed bed Reactor. hMSC-TERT Cells Were Grown in an $100 \mathrm{~cm}^{3}$ FBR, and then Washed Twice with PBS Without $\mathrm{Ca}^{2+} / \mathrm{Mg}^{2+}$. The Enzyme Solution $\left(30 \mathrm{~mL}\right.$, AccutaseTM $\sim 600 \mathrm{U} / \mathrm{mL}^{\text {or TrypZean }}{ }^{\mathrm{TM}}$ ) was Added and the Cells in the FBR were Incubated at Room Temperature $\left(21^{\circ} \mathrm{C}\right)$ for 10,15 or 20 min. Detached Cells were Counted by a Hemacytometer. Harvest yield was Calculated from the Cell Number before Detachment (Calculated as Described in [4]) and the Cell Number after Detachment

\begin{tabular}{|c|c|c|}
\hline \multirow{2}{*}{$\mathbf{t}_{\text {detachment }}$} & \multicolumn{2}{|c|}{ Detachment yield [\%] } \\
\cline { 2 - 3 } & Accutase $^{\mathrm{TM}}$ & TrypZean $^{\mathrm{TM}}$ \\
\hline \hline $10 \mathrm{~min}$ & $53 \pm 29$ & $43 \pm 11$ \\
\hline $15 \mathrm{~min}$ & n.d. & $41 \pm 4^{*}$ \\
\hline $20 \mathrm{~min}$ & $59 \pm 5^{*}$ & $69 \pm 9$ \\
\hline
\end{tabular}

n.d. not detected, $n=3, * n=2$

case, it is more likely that during the longer incubation time, TrypZean $^{\mathrm{TM}}$ damaged the surface proteins of the hMSCTERT, leading to subsequent cell death. Only hMSC-TERT detached after 15 min TrypZean ${ }^{\mathrm{TM}}$ treatment retained a high viability after encapsulation $(89.3 \pm 3.1 \%$ (0h)-87.4 $\pm 5.7 \%$ (24h)-81.0 $\pm 1.9 \%(48 \mathrm{~h}))$. Nonetheless, the harvest yield was only $41 \pm 4 \%$ for that scenario.

The detachment experiments of hMSC-TERT grown in an FBR demonstrated the difficulties of this process. The good preliminary results after detachment with Accutase $\mathrm{TM}^{\mathrm{TM}}$ and TrypZean ${ }^{\mathrm{TM}}$ in static well plates were not transferable to the dynamic situation in the FBR. Cell growth in the FBR differs depending on the heterogeneity of the system and the heightened shear stress compared to static cell growth. This environment reduces growth rate $\left(\bar{\mu}=0.37 \pm 0.01 \mathrm{~d}^{-1}\right)$ when compared to a static system $\left(\bar{\mu}=0.52 \pm 0.07 \mathrm{~d}^{-1}, \mathrm{p}<0.05\right)$. The preloading of the cells depending on the cultivation environment combined with the higher shear levels during harvest in the FBR are one explanation for the differences in results in the static and the dynamic FBR system. One thing is certain, the heterogeneity in the FBR leads to a heterogeneous distribution of the enzyme in the reactor. These large enzyme concentration differences inside the fixed-bed result in different detachment zones. In a high enzyme concentration zone, detachment can be complete, whereas in a low enzyme concentration zone, the cells can still be attached and then torn off when medium is flushed through the FBR. Thus, the harvest yield from the FBR and the cell viability of the detached and encapsulated cells were significantly lower. For a therapeutic approach, encapsulated hMSC-TERT need to have cell viabilities exceeding $90 \%$, which should stay stable during recultivation. In combination with the conditions in the FBR, neither of the two enzymes could fulfill all the requirements for hMSC-TERT detachment to enable therapeutic applications of these cells as capsules.

\subsection{Harvest of hMSC-TERT Expanded in a Stirred Tank Reactor}

As described above, it was difficult to harvest hMSCTERT from the FBR. This was due to the heterogeneity and the shearing in the reactor. As the situation in a stirred tank reactor (STR) is more homogenous, the hMSC-TERT expansion and detachment was set up in a STR system [3, 8].
Similar to the FBR the growth surface was provided by glass-coated carriers. To minimize shear stresses from the dynamic cultivation mode, a low-shearing marine impeller with low agitation was used. The higher homogeneity in the STR should allow for a homogenous distribution of the detachment enzyme and thus a more homogenous cell detachment. As the detachment with TrypZean ${ }^{\mathrm{TM}}\left(21^{\circ} \mathrm{C}\right.$, 15 minutes incubation) gave the best outcome for hMSCTERT harvest from the FBR, only this condition was investigated for hMSC-TERT expanded in the STR. With this experimental setup, $68 \pm 13 \%(n=3)$ of the cells grown in the STR could be detached. This was high compared to the harvest using same conditions from the FBR, but leaves room for improvement, as $100 \%$ harvest yields are desired. The detached hMSC-TERT expanded in the STR exhibited high viability $>99 \%$ after encapsulation (Fig. 5). The viability remained constant over the whole recultivation period, indicating more gentle conditions during harvest. These results indicated that greater homogeneity inside the STR seemed to be preferable for the hMSC-TERT harvest. Although detachment yield still needs to be increased, the quality of the detached and encapsulated hMSC-TERT was satisfactory for an application of the cell capsules as ATMP.

\section{CONCLUSION}

To enable broad usage of hMSCs as ATMPs, expansion processes have to be established and evaluated to ensure efficiency, reproducibility, stability and the desired outcomes. In this special case, the outcome is strongly connected to the quantity and quality of the expanded cells. As hMSCs represent the final product, the cell detachment and further processing are highly significant due to their direct effects on the product quality. Therefore, the detachment cannot be analyzed as a single event, but rather must be considered in combination with the expansion and encapsulation procedure to achieve meaningful results. With respect to the whole process the detachment yield and the hMSC viability is influenced by:

- the detachment enzyme (enzyme must cut proteins responsible for cell-cell- and cell-substrate-adhesion, should not damage cells)

- the enzyme incubation parameters (concentration, temperature, duration; maximize detachment yield and minimize cell damage) 


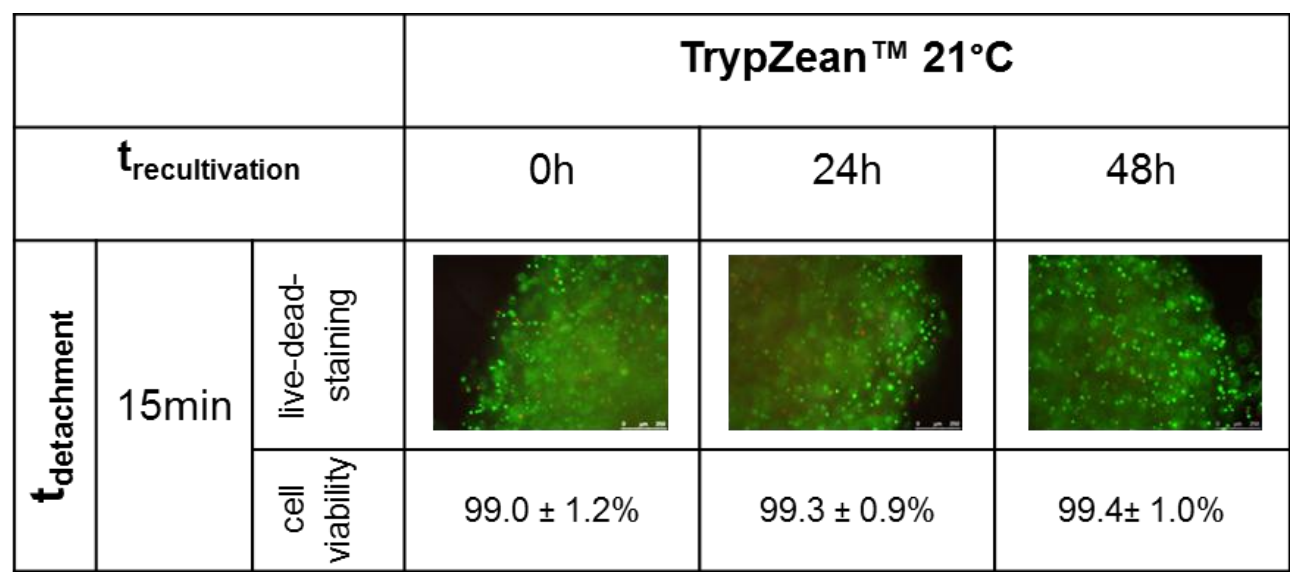

Fig. (5). hMSC-TERT encapsulated in alginate after enzymatic detachment from borosilicate carriers in a stirred tank reactor $\left(21^{\circ} \mathrm{C}\right)$. $\mathrm{hMSC}$ TERT were grown in a $3 \mathrm{~L}$ STR, washed twice with PBS without $\mathrm{Ca}^{2+} / \mathrm{Mg}^{2+}$. The enzyme solution $\left(0.13 \mathrm{~mL} / \mathrm{cm}^{2}, \mathrm{TrypZean}{ }^{\mathrm{TM}}\right)$ was added and the carriers were incubated at room temperature $\left(21^{\circ} \mathrm{C}\right)$ for $15 \mathrm{~min}$. Detached cells were encapsulated in alginate. The capsules were recultivated in hMSC-TERT culture medium in 6-well-plates for $48 \mathrm{~h}$ at $37^{\circ} \mathrm{C}$. The cell viability was analyzed by live-dead staining. Viable/intact cells were stained green whereas damaged/dead cells were stained red.

- the cell growth surface (should allow both attachment and detachment)

- $\quad$ using static or dynamic expansion (dynamic expansion often higher cell shearing, decreases cell viability after detachment)

- the homogeneity in the expansion system (homogenous distribution of the enzyme solution important)

- further processing of the cells after detachment (any processing step increases shear load of the cells and thus could decrease cell viability)

This study investigated some of these influence factors on hMSC-TERT detachment. A suitable growth surface allowing cell attachment, growth and detachment had been identified in previous studies. For hMSC-TERT borosilicate glass was ideal giving high growth rates and high detachment yields [5]. For the enzyme choice, first the enzymes had to fulfill the basic requirements for hMSC harvest for ATMP production. Out of four commercially available detachment enzymes (Accutase ${ }^{\mathrm{TM}}$, Alfazyme, Collagenase and TrypZean ${ }^{\mathrm{TM}}$ ), Collagenase and Alfazyme were excluded due to low detachment yields. For the remaining two enzymes incubation parameters (temperature, duration) were varied. To conclude a general finding which parameters were best is difficult. Using same parameters, detachment yield differs between the static and dynamic cultivation mode and between different reactor systems (FBR, STR). $100 \%$ of the cells were live detached from static systems after $10 \mathrm{~min}$ at $21^{\circ} \mathrm{C}$. Complete cell detachment in dynamic systems was only possible with a loss in cell viability. Moreover cell viability was not only depended on the incubation parameters but mainly on further cell processing. This was shown as in most cases hMSCTERT were highly viable direct after cell detachment. Only if hMSC-TERT were further processed (in this study encapsulated with alginate) a decrease in cell viability with increasing detachment temperature and duration could be detected. Accutase ${ }^{\mathrm{TM}}$, which worked well in the static monolayer experiments, was found to be unsuitable for hMSC-TERT detachment from the dynamic FBR.
TrypZean ${ }^{\text {TM }}$ yielded more promising results after 15 min enzyme exposure in both dynamic reactor systems (FBR, STR). Providing that dynamic hMSC-TERT expansion should be favored and detached hMSC-TERT should be encapsulated, an expansion in a STR using glass-coated carriers with a subsequent detachment using TrypZean ${ }^{\mathrm{TM}}$ (incubation $15 \mathrm{~min}, 21^{\circ} \mathrm{C}$ ) gave the best outcome. With this scenario a detachment yield of $68 \%$ and cell viabilities after encapsulation about $99 \%$ could be achieved.

Finally, the problem of cell detachment in an ATMP production process cannot be solved by choosing the right enzyme and its incubation conditions alone. Taking account of the shear stress in the expansion system and coordinating all steps in up- and downstream processing with respect to final ATMP quality are just as important. Further study should be devoted to determining whether other growth surfaces such as thermo responsive surfaces [23] can improve the detachment outcome from dynamic expansion systems, alone or in combination with a detachment enzymes. This issue must be solved if new enzymes from non-mammalian sources show more potential for a gentle but effective cell harvest from dynamic systems. At a minimum, problems of this nature in reactor set up have to be solved, as STR are not equipped for the detachment of cells from the carrier. Therefore, solutions can be sieve modifications as previously described by our workgroup [24].

\section{CONFLICT OF INTEREST}

The authors declare no conflict of interest.

\section{ACKNOWLEDGEMENTS}

hMSC-TERT were kindly provided by M. Kassem, University of Southern Denmark. The authors would like to thank the Hessen State Ministry of Higher Education, Research and Arts for their financial support within the Hessen initiative for supporting scientific and economic excellence (LOEWE-Program) as well as the Federal ministry of Economics and Technology. 


\section{REFERENCES}

[1] H. Hamada, M. Kobune, K. Nakamura, Y. Kawano, K. Kato, O. Honmou, K. Houkin, T. Matsunaga, and Y. Niitsu, "Mesenchymal stem cells (MSC) as therapeutic cytoreagents for gene therapy," Can. Sci., vol. 96, pp. 149-156, 2005.

[2] D. Freimark, P. Pino-Grace, S. Pohl, C. Weber, C. Wallrapp, P. Geigle, R. Pörtner, and P. Czermak, "Use of encapsulated stem cells to overcome the bottleneck of cell availability for cell therapy approaches," Transfusion Med. Hemoth., vol. 37, pp. 66-73, 2010.

[3] K. Cierpka, C. L. Elseberg, K. Niss, M. Kassem, D. Salzig, and P. Czermak, "hMSC Production in Disposable Bioreactors with Regards to GMP and PAT," Chemie Ingenieur Technik, vol. 85, pp. $67-75,2013$

[4] C. Weber, S. Pohl, R. Poertner, P. Pino-Grace, D. Freimark, C. Wallrapp, P. Geigle, and P. Czermak, "Production process for stem cell-based therapeutic implants - Expansion of the production cell line and cultivation of encapsulated cells," In: Advances in Biochemical Engineering/Biotechnology. C. Kasper, M. van Griensven, and R. Poertner, Eds., Berlin: Springer, pp. 143-162, 2010.

[5] C. Weber, S. Pohl, R. Portner, C. Wallrapp, M. Kassem, P. Geigle, and P. Czermak, "Expansion and Harvesting of hMSC-TERT," Open Biomed. Eng. J., vol. 1, pp. 38-46, 2007.

[6] C. Weber, S. Pohl, P. Pino Grace, D. Freimark, C. Wallrapp, P. Geigle, and P. Czermak, "Expansion of human mesenchymal stem cells in a fixed-bed bioreactor system - Part A: Inoculation, cultivation, cell harvest procedures," Int. J. Artif Organs, vol. 33, pp. 512-525, 2010.

[7] C. Weber, S. Pohl, R. Poertner, P. Pino Grace, D. Freimark, C. Wallrapp, P. Geigle, and P. Czermak, "Expansion of human mesenchymal stem cells in a fixed-bed bioreactor system - Part B: Modeling and scale up," Int. J. Artif Organs, vol. 33, pp. 782-795, 2010.

[8] C. L. Elseberg, J. Leber, D. Salzig, C. Wallrapp, M. Kassem, M. Kraume, and P. Czermak, "Microcarrier-based expansion process for hMSCs with high vitality and undifferentiated characteristics," Int. J. Artif Organs, vol. 35, pp. 93-107, Feb 2012.

[9] O.-W. Merten and M. C. Flickinger, "Cell Detachment," in Encyclopedia of Industrial Biotechnology: Bioprocess, Bioseparation and Cell Technology, John Wiley \& Sons, Inc., pp. 1-22, 2009.

[10] FDA, "FDA Proposes Barring Ceratin Cattle Material From Medical Products As BSE Safeguard," 2007.

[11] H. E. Canavan, X. Cheng, D. J. Graham, B. D. Ratner, and D. G. Castner, "Cell sheet detachment affects the extracellular matrix: A surface science study comparing thermal liftoff, enzymatic, and mechanical methods," J. Biomed. Mat. Res. Part A, vol. 75A, pp. 1-13, 2005.

[12] F-P. Wachs, S. Couillard-Despres, M. Engelhardt, D. Wilhelm, S. Ploetz, M. Vroemen, J. Kaesbauer, G. Uyanik, J. Klucken, C. Karl, J. Tebbing, C. Svendsen, N. Weidner, H.-G. Kuhn, J. Winkler, and L. Aigner, "High Efficacy of Clonal Growth and Expansion of Adult Neural Stem Cells," Lab. Invest., vol. 83, pp. 949-962, 2003.

[13] R. Bajpai, J. Lesperance, M. Kim, and A. V. Terskikh, "Efficient propagation of single cells accutase-dissociated human embryonic stem cells," Mol. Reprod. Develop., vol. 75, pp. 818-827, 2008.

[14] M. Vielreicher, G. Harms, E. Butt, U. Walter, and A. Obergfell, "Dynamic interaction between Src and C-terminal Src kinase in integrin alphaIlbbeta3-mediated signaling to the cytoskeleton," $J$. Biol. Chem., vol. 282, pp. 33623-33631, 2007.

[15] I. Grimm, S. N. Ullsperger, and H. Zimmermann, "Nucleotides and epidermal growth factor induce parallel cytoskeletal rearrangements and migration in cultured adult murine neural stem cells," Acta Physiol, vol. 199, pp. 181-189.
[16] E. Lasfargues and D. Moore, "A method for the continuous cultivation of mammary epithelium," In Vitro Cell Develop. Bio. Plant, vol. 7, pp. 21-25, 1971.

[17] E. Sjögren-Jansson, M. Zetterström, K. Moya, J. Lindqvist, R. Strehl, and P. S. Eriksson, "Large-scale propagation of four undifferentiated human embryonic stem cell lines in a feeder-free culture system," Develop. Dyn., vol. 233, pp. 1304-1314, 2005.

[18] S. Rourou, A. v. d. Ark, T. v. d. Velden, and H. 1. Kallel, "Development of an Animal-Component Free Medium for Vero Cells Culture," Biotechnol. Prog., vol. 25, pp. 1752-1761, 2009.

[19] J. M. Wiehe, Z. Kaya, J. M. Homann, J. Wöhrle, K. Vogt, T. Nguyen, W. Rottbauer, J. Torzewski, N. Fekete, M. Rojewski, H. Schrezenmeier, B. Moepps, and O. Zimmermann, "GMP-adapted overexpression of CXCR4 in human mesenchymal stem cells for cardiac repair," Int. J. Cardiol., vol. available online, 2012.

[20] J. L. Simonsen, C. Rosada, N. Serakinci, J. Justesen, K. Stenderup, S. I. S. Rattan, T. G. Jensen, and M. Kassem, "Telomerase expression extends the proliferative life-span and maintains the osteogenic potential of human bone marrow stromal cells," Nat. Biotech., vol. 20, pp. 592-596, 2002.

[21] M. Butler, Animal Cell Culture and Technology - The Basics. New York: Oxford University Press, 2004.

[22] C. Justice, J. Leber, D. Freimark, P. Pino Grace, M. Kraume, and P. Czermak, "Online- and offline- monitoring of stem cell expansion on microcarrier," Cytotechnology, pp. 1-11, 2011.

[23] J. Teichmann, M. Valtink, S. Gramm, M. Nitschke, C. Werner, R. H. W. Funk, and K. Engelmann, "Human corneal endothelial cell sheets for transplantation: Thermo-responsive cell culture carriers to meet cell-specific requirements," Acta Biomater, vol. 9, pp. 5031-5039, 2013.

[24] C. Elseberg, P. Grace, D. Salzig, and P. Czermak, "Device and for expansion and harvest of adherent cells,," EP12000816.6 2012.

[25] E. Zini, M. Franchini, F. Guscetti, M. Osto, K. Kaufmann, M. Ackermann, T. A. Lutz, and C. E. Reusch, "Assessment of six different collagenase-based methods to isolate feline pancreatic islets," Res. Vet. Sci., vol. 87, pp. 367-372, 2009.

[26] K. S. Stenn, R. Link, G. Moellmann, J. Madri, and E. Kuklinska, "Dispase, a neutral protease from Bacillus polymyxa, is a powerful fibronectinase and type IV collagenase," J. Investig. Dermatol., vol. 93, pp. 287-90, 1989.

[27] J. M. Harlan, P. D. Killen, L. A. Harker, G. E. Striker, and D. G Wright, "Neutrophil-mediated Endothelial Injury In Vitro," J. Clin. Invest., vol. 68, p. 10, 1981.

[28] C. M. Flickinger and W. S. Drew, "Encyclopedia of bioprocess technology: Fermentation, Biocatalysis and Bioseperation," John Wiley \& Sons, Inc, vol. 1-5, 1999.

[29] C. Waymouth, "To disaggregate or not to disaggregate, injury and cell disaggregation, transient or permanent?," In Vitro Cell Develop. Biol. - Plant, vol. 10, pp. 97-111, 1974.

[30] J. M. Berg, J. L. Tymoczko, and L. Stryer, "Stryer Biochemie," Spektrum Akademischer Verlag, 2007.

[31] Z. Wu, G. Jiang, P. Xiang, D. Yang, and N. Wang, "Purification and characterization of trypsin-like enzymes from North Pacific krill.," Biotechnol. Lett., vol. 30, pp. 67-72, 2008.

[32] C. Ellerström, R. Strehl, K. Noaksson, J. Hyllner, and H. Semb, "Facilitated Expansion of Human Embryonic Stem Cells by SingleCell Enzymatic Dissociation," Stem Cells, vol. 25, pp. 1690-1696, 2007.

[33] J. Litwin, "Standardization of Human Diploid Fibroblast Cultivation: Trypsinization Procedure," Appl. Microbiol., vol. 21, pp. 169-174, 1971.

[34] J. Seidel, G. E., M. L. Turk, P. W. Gordy, and R. A. Bowen, "240

Recombinant bovine trypsin made in maize inactivates bovine herpes virus-1 adsorbed to the bovine zona pellucida " Reprod. Fertil Develop., vol. 19, pp. 236-236, 2006.

Received: September 19, 2013

Revised: November 11, 2013

Accepted: December 11, 2013

(C) Salzig et al.; Licensee Bentham Open.

This is an open access article licensed under the terms of the Creative Commons Attribution Non-Commercial License (http://creativecommons.org/licenses/by-nc/3.0/) which permits unrestricted, non-commercial use, distribution and reproduction in any medium, provided the work is properly cited. 